JEL J7, H7

\title{
Gender Equality and Women Participation in Government: the case of Kazakhstan ${ }^{1}$
}

\author{
A.A. Kireyeva ${ }^{1}$, G.K. Kenzhegulova ${ }^{2}$, Rajkhan Osama ${ }^{3}$ \\ ${ }^{1}$ Institute of CS MES RK, ${ }^{2}$ NARXOZ University, ${ }^{3}$ American University of Sovereign Nations
}

\begin{abstract}
Gender equality today is gaining all the relevance in the planning of the State program around the world. When planning government programs, they follow certain steps to achieve this goal. However, the goal of this system remains acute in many countries around the world. This article is devoted to the issue of gender policy in Kazakhstan. The article examined indicators such as women's participation in leadership positions, employment in the labor market, education, the wage gap and how they participate in women's participation in parliament. The participation of women in parliament was identified as one of the key factors in the development of gender equality. The article considered the theory of context. The results of the study confirmed the theory of context. To promote gender equality policies, the application of policies must be considered. The results showed that the wage gap and women's participation in the labor market have a significant impact on women's participation in parliament. The activity of women in education, that is, the increase in the number of women among students, however, did not have a significant impact on the participation of women in parliament. The SPSS program was used for the regression analysis. Also, a statistical analysis was carried out for a deeper study of the influence of factors on the activity of women in the state. The SPSS program was used for the regression analysis.

Key words: public policy, gender equality, government, parliaments, education, labor force, wage gap.
\end{abstract}

\section{Гендерлік теңдік және әйелдердің мемлекеттік басқаруға қатысуы: Қазақстан мысалында}

\section{Түйін}

Гендерлік теңдік бүгінде бүкіл әлемде Мемлекеттік бағдарламаны жоспарлауда үлкен өзектілікке ие болуда. Мемлекеттік бағдарламаларды жоспарлау кезінде олар осы мақсатқа жету үшін белгілі бір қадамдарды орындайды. Алайда, бұл жүйенің мақсаты әлемнің көптеген елдерінде өткір болып қалуда. Бұл мақала Қазақстандағы гендерлік саясат мәселесіне арналған. Мақалада әйелдердің басшылық қызметке қатысуы, еңбек нарығындағы жұмыспен қамту, білім, жалақы айырмашылығы және олардың әйелдердің парламенттегі жұмысына қатысуы сияқты көрсеткіштер қарастырылды. Мақалада контекст теориясы қарастырылды. Зерттеу нәтижелері контекст теориясын растады. Гендерлік теңдік саясатын ілгерілету үшін саясатты қолдану мүмкіндігі карастырылуы керек. Нәтижелер көрсеткендей, жалақы айырмашылығы және әйелдердің еңбек нарығына қатысуы әйелдердің парламентке қатысуына айтарлықтай әсер етеді. Әйелдердің білім берудегі белсенділігі, яғни студенттер арасында әйелдер санының көбеюі, алайда әйелдердің парламенттегі жұмысына айтарлықтай әсер етпеді. Регрессиялық талдау үшін SPSS бағдарламасы қолданылды. Сондай-ақ, штаттағы әйелдер белсенділігіне факторлардың әсерін тереңірек зерттеу үшін статистикалық талдау жүргізілді. Регрессиялық талдау үшін SPSS бағдарламасы қолданылды.

Tүйін сөздер: мемлекеттік саясат, гендерлік теңдік, үкімет, парламент, білім, жұмыс күші, жалақы айырмашылығы

\section{Гендерное равенство и участие женщин в правительстве: на примере Казахстана}

Гендерное равноправие на сегодняшний день набирает все большую актуальность в планировании государственной программы по всему миру. Государственные программы при планировании следуют определенным шагам достижения данной цели. Тем не менее, достижение этой цели остается острым во многих развивающихся странах среди которых есть страны Азии и СНГ. Данная статья посвящена вопросу гендерной политики в Республике Казахстан. В статье были рассмотрены такие показатели как участие женщин на руководящих позициях, занятость на рынке труда, образование, разрыв в заработной плате и как они влияют на участие женщин в парламенте. Участие женщин в парламенте было определено как один из ключевых факторов развития гендерного равноправия. В статье рассматривалась теория контекста. Результаты исследования подтвердили данную теорию. Для продвижения политики гендерного равноправия необходимо учитывать контекст применения политики: историю развития страны, социокультурный фактор населения, обеспеченность и тд.. Результаты показали, что разрыв в заработной плате и женское участие на рынке труда оказывают значительное влияние на участие женщин в парламенте. Активность женщин в образовании, то есть, увеличение количества женщин среди студентов, однако, не показали значительного влияния на участие женщин в парламенте. Для проведения регрессионного анализа была использования программа SPSS. Также, было проведен статистический анализ для более глубокого изучения влияние факторов на активность женщин в государстве.

Ключевые слова: государственная политика, гендерное равенство, правительство, парламенты, образование, рабочая сила, разрыв в заработной плате

1 This research has been supported by the Ministry of Education and Science of the Republic of Kazakhstan within the project «The science impact on Kazakhstan's socio-economic development: methodology, assessment models and development scenarios» (IRN AP08052745). 


\section{Introduction}

Gender equality (GE) has been the target of most of the countries in the process of pursuing women rights. Moreover, GE achievement is another way of achieving Goals of Sustainable development (SDG)[1]. The context of achieving women rights and overcoming glass blocks has a great impact on GE implementation. Countries, which are more of democracy regime, for instance western countries, are more successful in achieving goals for GE.

At the same time, pure Muslim countries seem less friendly toward GE or adoption of new laws, which favor feminist movements. This is especially urgent in Asian countries as they are mostly described as being influenced by cultural standards or perception of society. Another characteristic is that they are dependent on their religious and national traditions of housekeeping. Moreover, authoritarian regime of a country management also leaves its male footprint. For these countries, it is difficult to achieve gender equality due to existing and hidden barriers [2]. Kazakhstan as country with a mixed religious view, yet among the countries with low democracy indicator, is struggling in the achievement of GE as well.

One of the factors that contribute to this general dissatisfaction is its authoritarian heritage, a consequence of a bureaucracy largely governed by men. Nevertheless, Kazakhstan has been promoting women participation in all spheres as well as in the process of policymaking.

Issues related to gender equality, like women support, are one of the top SDG goals. Even though Kazakhstan has started its path in order to eliminate women discrimination at all levels, more vivid results could have emerged almost 20 years later. In 2012, women made up 25,2\% of Mazhilis Parliament; in 2014 we can see that there were only three women holding positions of ministers (Ministry of Health, Ministry of Labor and Social Protection for the Public, Ministry of Economic Integration) out of 20. In 2018, women made up already $27 \%$ of the parliament. Yet, it remains tokenistic [3]. International organizations' support, like the "Arnasay" project, has shown the importance of involving women in STEM because of its significance to the letter and spirit of the SDGs Agenda.

Being a developing country, Kazakhstan has developed in many aspects thus expanding the range of opportunities for women. Nevertheless, there are still some gaps. Therefore, our research aims at studying the outcome of government efforts in provision of GE with its further impact on women participation in government. The object of our research are women, as our paper is devoted to the study of gender equality. In particular, we are considering improvements in favor of women rights. The subject of our research is their participation in politics and economy from 2010 to 2019 . The indicators of women activity are presented and discussed in the methodology part.

While, previous studies in most cases regard women's increasing interest and participation in education as a part of a holistic policy. The case of Kazakhstan is most likely going to contribute to the development of gender equality policy in CIS countries where access to education for women was much more available compared with other developing countries. The result of our study will help develop further recommendations related to the provision of gender equality under the current conditions of COVID-19 taking into account the progress that has been achieved and policy challenges that remain in Kazakhstan.

\section{Literature review}

As greater awareness of gender discrimination in society keeps growing, Kazakhstan has passed through a gender policy transformation period since joining the Beijing Platform of Action as an independent state in 1992. At the same time, however, the acquired independence from the former Soviet Union can be characterized by regressive development trends in terms of gender equality; while women gained the right to education, there appear to be more glass ceilings [3]. The way an issue is presented; i.e., as having great importance or impact can influence our response to it [1]. Therefore, the context of gender equality development in some studies is defined as one of the key factors, which has a major impact on GE $[3,4]$. Authors stress that GE is achieved through women's economic empowerment, the content of which is defined by the accessibility to education, political representation, participation in the economy as occupying leading positions or labor force volume [5].

Connel (2006) studied GE movements through the analysis of four dimensions as culture, labor, power, and relationships. The study was an organization-based investigation. However, it shows the importance of context and perspectives on related issues [6].

Epple and Schief (2016) in their study discussed the methods of achieving GE. They mentioned three factors which were: women in a leading position, work division, and payment gaps. Importantly, under the division of labor, they included paid work as well as volunteering or unpaid labor where women regard unpaid work as a freedom of choice [3]. In some studies, education accessibility stands out as a factor of freedom of choice. This is when a woman decides to continue her education for financial independence, courier ladder, or support of her family. Park and Liang (2019) in their study emphasized that active political 
representation of women has a positive impact on GE development. The growth of women>s institutional representation and social outcomes (as education, labor force, higher salaries) are regarded as having a positive impact on economic growth [5].

Women>s political representation is widely studied as growing in line with women $>$ s access to education, improvement of women $>$ s rights, wage gap reduction, and their occupation of top positions. However, the increase of women in politics, i.e. as members of national parliaments, can also be the effect of women>s economic activity. [4]

The beginnings of women>s empowerment could be traced back to the classical school of management.

Although the studies provided were done based on factories [7] wages where women typically earned substantially less than men. Gender issues had been, however, considered, but not emphasized. For example, researchers like Henry Fayol, Elton Mayo, Talcott Parsons, developed theories of formal and informal groups at work, like the concept of individual and group operation, etc. as pay discrimination was a concern. It is worth mentioning that any form of women's discrimination has led to several studies in that mainstream. Particularly in Kazakhstan, many studies in terms of gender inequality are based on women's discrimination, domestic violence, or violation of women's rights.

While most of the studies are devoted to discussion of women empowerment issues, some researchers, quite often, associated empowerment with economic independence. This is their participation in labor mostly (the access or lack of workplaces for women). Still, this is tightly discussed with wage gaps between women and men. Some studies show evidence that women lose their interest in a particular field when the wage gap is rather high. Other studies talk about the positive or negative impact of wage gaps in different regions. For instance, in the Asian region, the wage gap has quite a positive outcome as the women labor force is more available and more attractive to hire. However, this is not the same for OECD countries. Also, education access for women, increasing their decision-making freedom, had a positive projected influence on GDP per capita [8].

These days, studies of the positive influence of women's occupation of leading positions are trending. Nevertheless, leading positions in different fields have different levels of decisionmaking power. Thus, women undergo different ways of evaluations of their professional skills. A fine illustration of that is women in prosecutorial positions or judges, where they are usually checked for such values as credibility or equity [9]. In addition, men sometimes find it difficult to accept women achieving top positions. Therefore, it leads to misunderstanding and has put women into the process of skills evaluation again [6].

As it is clear, the majority of the literature provides studies of GE policy implementation based on organizations or economic fields. Notwithstanding, most of the research is based on the dimensions provided by the State Gender Equality Policy which includes the labor force, wage gap, top positions, representativeness in politics and education. Still, education and politics are more often defined as separate factors and the rest are given as a combination due to high dependency on each other. There is a growing number study of GE policy ways of achievement. However, the context of GE policy implementation needs deeper analysis.

\section{Theoretical framework}

These days the literature on feminist movements for women rights or attempts of a country to achieve set goals on the way to gender equality is growing. There is a great number of studies which are devoted to women participation in education on the whole, starting from the rate of female students in male dominated subjects to the occupations. Due to this, there is developing a great number of studies, which discuss women empowerment in government through their occupational position across non-elective decisionmaking positions. These studies touch upon feminized sectors of economy, whereas women mostly occupy low-paid positions. Decision making positions are dominated by men, which shifts back the achievement of GE goals [10]. There is a growing number of studies about the attitudes and implementation of GE across Muslim countries with authoritarian regime [11]. High attention is given to widespread issues. First of all this is lack access to education and digital illiteracy. Sociocultural obstacles are also being studied. One of the prominent ones is subordination performed by women. By this, authors stress absence of women's voices in any aspects, as Muslim countries as Jordan, Turkey, Egypt, Morocco and etc., are male dominated in all spheres and the lifestyle in these countries is closely attributed to religious and cultural traditions $[11,12,13]$. Other studies are exploring the impact of running conditions in a country, thus showing the importance of the context [3]

Summing up the literature review provided, we defined four factors, which are mostly discussed as having influence on women participation in government. There is a great number of studies, which discuss the importance of women access to higher education as both students and academic staff. Another topic being discussed is the access of women to executive or decision making 
positions. Studies about women economic activity consider women labor force and gender wage gap as important factors of economic growth. All mentioned factors are the key components in the achievement of gender equality. Therefore, this research will analyze the effect of GE goals implementation in the context of Kazakhstan.

\section{Methodology}

Although many studies discuss and investigate the significance of achieving gender equality in education through increasing the popularity of scientific participation among women, other studies show the concern of some governments in the provision of GE in education. Depending on the country's situation, the education level may change from primary school to higher education access [14].

In our study, we are going to follow the three components analysis, which is described in the study of Epple and Schief (2016). They underline the contents of gender equality policy, which are the (1) share of women in decision-making positions or executive positions, (2) wage gap and, (3) gendered division of labor, which includes housework and voluntary activity.

In our study, we are narrowing our research and taking the lead of recent research. Firstly, depending on the study of Kabeer and Natali (2013) we are taking women in parliament, wage gap, and women in leading positions [15]. Depending on the literature review, we have added two other factors as independent variables as follows :

1. The share of women entering higher education (WHE). According to the literature review, authors are discussing the impact of family relationships, where the decision to study is the result of gender equality in family-made decisions. From our point of view, it also falls under the category of unpaid labor. By deciding to study, women invest in their future rather than providing unpaid labor with vague possibility for future earnings. Moreover, women participation in education has a positive impact on GDP per capita $[16,17]$.

2. We are taking ratio of women wages (WWG). During our data collection, there were no data for 2003 and 2004. Depending on the fact that the changes in the minimum wage was in 2005 and the previous years there were no changes, we took the mean value for the missing 2 years. (WLP).

3 . We are taking women in leading positions

4. As a dependent variable, we are taking the share of women in National Parliament (WNP). By national parliament, we mean members of Senate and Mazhilis together.

Table 1 - Used variables

\begin{tabular}{|l|l|l|l|l|}
\hline No. & $\begin{array}{l}\text { Abbrevi } \\
\text { ation }\end{array}$ & \multicolumn{1}{|c|}{ Variable } & \multicolumn{1}{|c|}{ Description } & \multicolumn{1}{|c|}{ Source for data collection } \\
\hline 1 & WNP & Dependent & $\begin{array}{l}\text { Proportion of seats held by women } \\
\text { in national parliaments (\%) }\end{array}$ & World bank \\
\hline 2 & WLF & Independent & $\begin{array}{l}\text { Labor force, female (\% of total labor } \\
\text { force) }\end{array}$ & World bank \\
\hline 3 & WLP & Independent & $\begin{array}{l}\text { Share of women, occupying leading } \\
\text { positions (\%) }\end{array}$ & $\begin{array}{l}\text { Agency for strategic planning and reforms } \\
\text { of the Republic of Kazakhstan }\end{array}$ \\
\hline 4 & WHE & Independent & $\begin{array}{l}\text { Share of women in higher education } \\
(\%)\end{array}$ & $\begin{array}{l}\text { Agency for strategic planning and reforms } \\
\text { of the Republic of Kazakhstan }\end{array}$ \\
\hline 5 & WWG & Independent & $\begin{array}{l}\text { Ratio of women's wages to men's } \\
\text { wages (\%) }\end{array}$ & $\begin{array}{l}\text { Agency for strategic planning and reforms } \\
\text { of the Republic of Kazakhstan }\end{array}$ \\
\hline
\end{tabular}

The limitation of our study includes the lack of information for WLP, WHE, and WWG variables. Thereby, we are considering data from 2001 to 2019 . Therefore there have been eveloped following hypothesizes.

1.Women in Kazakhstan have become more active. As women become more active, their participation in National Parliaments becomes active as well.

2.Women participation in National Parliaments does not depend on women active participation of GE goals.
3. GE policy goals, which are achieved in terms of crosscutting issues do not increase women participation in National Parliaments.

This study is based on secondary data of women s participation in different fields. For data processing, we used the Pearson Correlation and Multiple Regression SPSS software. Descriptive statistic was used for provision of a full analysis of the results obtained. Thus this study is based on the public data. 


\section{Results and discussion Results}

Table 2 - Pearson Correlation

\begin{tabular}{|c|c|c|c|c|c|}
\hline \multicolumn{6}{|c|}{ Correlation } \\
\hline & & $\begin{array}{c}\text { WLF (\% of total labor } \\
\text { force) }\end{array}$ & $\begin{array}{c}\text { WLP } \\
(\%)\end{array}$ & $\begin{array}{c}\text { WHE } \\
(\%)\end{array}$ & $\begin{array}{c}\text { WWG } \\
(\%)\end{array}$ \\
\hline \multirow{3}{*}{$\begin{array}{c}\text { WNP } \\
\text { Proportion of } \\
\text { seats held by } \\
\text { women in national } \\
\text { parliaments }(\%)\end{array}$} & Pearson Correlation &,$- 780^{* *}$ &, $597^{* *}$ &,$- 563^{*}$ &, $881^{* *}$ \\
\hline & Sig. (2-tailed) &, 000 &, 007 & ,012 &, 000 \\
\hline & $\mathbf{N}$ & 19 & 19 & 19 & 19 \\
\hline
\end{tabular}

Further, regression analysis is carried out in order to define how these variables are related.

Table 3 - Model Summary

\begin{tabular}{|c|c|c|c|c|}
\hline Model & $\mathrm{R}$ & $\mathrm{R}$ Square & Adjusted R Square & Std.Error of the Estimate \\
\hline 1 &, $951^{\mathrm{a}}$ &, 905 &, 878 & 2,4398 \\
\hline
\end{tabular}

Table 3 demonstrates information on the coefficient of determination. As we can see, $\mathrm{R}$ Square $=.91$; $\mathrm{R}$ Square explains that almost $91 \%$ of the change in Proportion of seats held by women in national parliaments (\%) is explained by the predictors taken as a set (the predictors are: Ratio of women's wages to men's wages (\%), Labor force participation, female ( $\%$ of total labor force),
Share of women occupying leading positions (\%), and Share of women in higher education (\%)).

The ANOVA, table 4, shows the following information. There is a large $F$ value that $(F(4,14)=33,3$ more than 30$)$ indicates a bigger difference between variables. Thus, $\mathrm{P}$-value of $\mathrm{F}$ statistics if less than $0,001(p<.001)$. Therefore, we can conclude that the fitted model is significant.

Table 4 - ANOVA.

\begin{tabular}{|c|l|c|c|c|c|c|}
\hline \multicolumn{2}{|c|}{ Model } & Sum of Squares & df. & Mean Square & F & Sig. \\
\hline \multirow{2}{*}{1} & Regression & 792,889 & 4 & 198,222 & 33,300 &, $000^{\text {b }}$ \\
\cline { 2 - 6 } & Residual & 83,337 & 14 & 5,953 & & \\
\cline { 2 - 6 } & Total & 876,226 & 18 & & & \\
\hline
\end{tabular}

Table 5 - Coefficients

\begin{tabular}{|c|c|c|c|c|c|c|c|}
\hline & B & Std.Err. & Bets & & & Tolerance & VIF \\
\hline (Constant) & 316,579 & 145,039 & & 2,183 & 047 & & \\
\hline $\begin{array}{l}\text { Labor force, female (\% of total labor } \\
\text { force) }\end{array}$ & $-8,161$ & 3,270 &,- 422 &,- 495 & ,026 & ,238 & 4,207 \\
\hline $\begin{array}{l}\text { Share of women, occupying leading } \\
\text { positions (\%) }\end{array}$ &,- 126 & ,306 &,- 046 &,- 413 & ,686 & ,555 & ,800 \\
\hline Share of women in higher education (\%) &,- 097 & ,602 &,- 023 &,- 162 &, 874 & ,334 & ,998 \\
\hline $\begin{array}{l}\text { Ratio of women's wages to men's } \\
\text { wages }(\%)\end{array}$ & 1,692 & 275 &, 670 & 6,141 & ,000 & ,571 & ,751 \\
\hline
\end{tabular}


The regression coefficients for WLP and WHE is insignificant as P-values are higher than the significance level ,686 and ,874 respectively. Whereas for the rest two WLF (Sig. $p=.026$ ) and WWG (Sig. $\mathrm{p}<0.001$ ), P-values are less than the significance level $(\alpha=5 \%)$. Therefore, there are two significant variables WWG and WLF. Nevertheless, the Beta data shows that, WLF has a negative impact $(-8,161)$ on WNP and WWG has a positive impact $(1,692)$. As Variance Inflation Factor (VIF) is less than 5, there is no multicollinearity. In samples which are less than 50 (in our case we have 19), less than 5 is acceptable.

The first hypothesis is rejected. Although women have become more active in four categories of gender equality goals their participation in national parliaments has not increased in line.

The second is partially rejected as there are two factors, which have a significant impact on women participation in National Parliament.

The third is confirmed. Women access to higher education has insignificant impact on women participation in National Parliament. Women have become more active in education, because government was solving cross-cutting issues related to education system on the whole.

\section{Discussion}

As above-mentioned, there are key four factors for GE, which are considered in the policy of gender equality achievement. These four factors are related to the economic sectors where women's representation is being improved by the states. Consequently, if there is a higher rate of women in the labor force, education, and leading positions in the government, which is their participation in national parliaments in decision-making positions also grows.

This article provides a combined analysis of three factors (labor force, leading positions and wage gap). Five fields are taken, which are highly popular among women. They are agriculture, industry, education, public health service and public administration (which is public administration and defense; compulsory social security). Other fields were not considered as the rate of women comprised about $4 \%$ or less in the following years 2001, 20019,2014 2019.

In 2001 women in agriculture made up about $35 \%$. However it showed downward trend in the following years, having decreased for more than three times and made up only $11,80 \%$. Women activity in industry showed downward trend in 2001, 2009, and 2014.

However, that it increased more than 2 times in 2019 and comprised about $20 \%$ of total women employed.
Interestingly, women economic activity in public health and public administration showed a steady growth and increased only for about $1 \%$ by the end of the considered period. Nevertheless, these categories do not include decision-making positions in politics.

Still, women involvement in education stays among the most popular ones. Being two times less than involvement in agriculture in 2001 we can follow a gradual increase in the following years. The difference with the base year of women involvement in education made up 5,9\%. Thus, women employment in education makes up $19,20 \%$ of total women employed, making it the second mostly feminized sectors of economy in Kazakhstan.

In terms of leading positions, women concentration in lower positions in education has a negative impact on women opportunities in public administration. Whereas women holding top positions as a rector of a university are more likely to continue their carrier in politics as one of the members of parliament. Moreover, if we study the curriculum vita of politicians, we will note one general characteristic. Parliament members usually hold $\mathrm{PhD}$ or had the experience of holding top positions at a higher educational institution.

This explains to us why women's occupation in leading positions does not have a significant impact on their participation in National Parliaments. The economic sector also plays a role in the development of opportunities for women to participate in National Parliament. Where there is a close cooperation with state bodies, i.e. Ministry of Education, there are higher opportunities for women to get involved in national parliaments.

Regarding income, the wage gap also plays a role in GE. In all four categories, there is a gradual increase. However, we can mark a quite sharp increase in 2016 and 2019 in all categories.

Interestingly, education and agriculture are less profitable compared to industry and public administration. Although, changes in education average salary has changed significantly, still it takes the second place from the bottom. Average salary in Industry is higher than other mentioned categories, which also explains a higher activity of women in the private sector, i.e. small and medium entrepreneurship.

Another factor, which is also counted as having an influence on women's participation in national parliaments, is education. Access to education for women still requires state support and is usually implemented as state grants or scholarships. Again, education is also regarded as an indicator of women's freedom of choice, preserving women's rights and their empowerment. Interestingly, education, being one of the most 
feminized sectors of the economy in Kazakhstan, has improved the content of women participation since 2004-2005. Women should be considered as both consumers and suppliers of education. As consumers, we need to look at the share of women who enter higher education with a Bachelor $>$ s or Masters >s degree. As seen in figure 1, the number of women participation in higher education (HE) has changed since 2004/2005. First, in 1999 the share of female students in HE made up 55,1\%, by 2003 it has increased by about 3\% and maintained around 58\% until 2013 and dropped in 2018 to just under 54\% and kept decreasing till the end of the period.

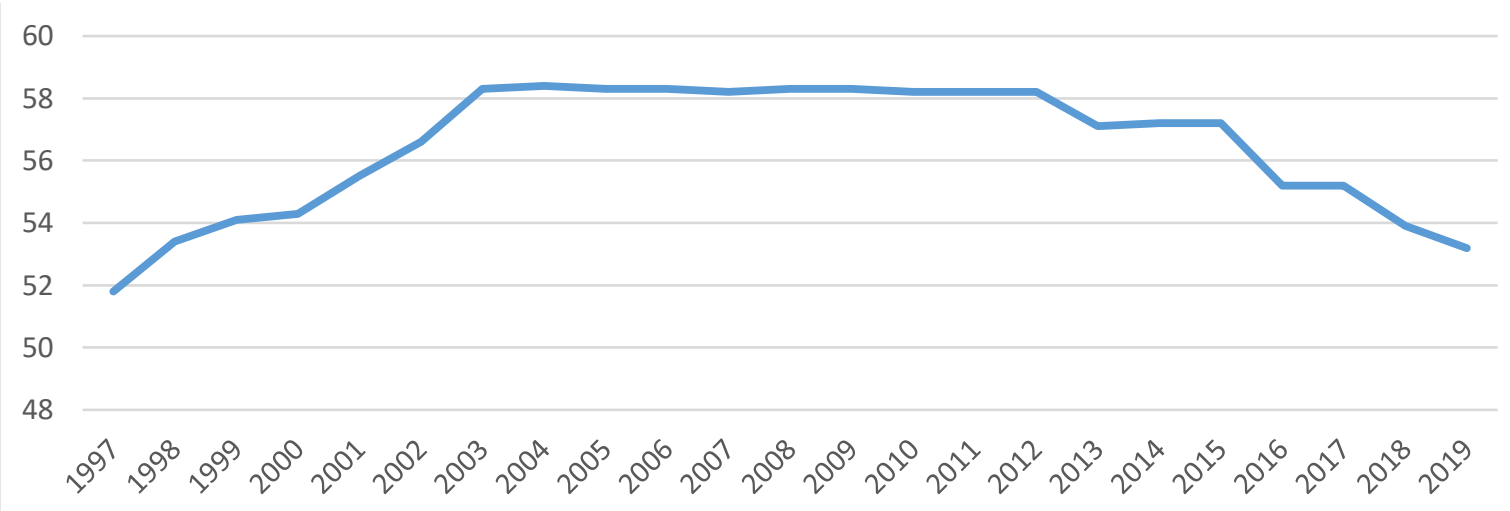

Figure 1 - Share of Women entering higher education (\%), Kazakhstan

To summarize, we need to highlight three main points. First, the introduction of the Bologna Declaration in Kazakhstan and further adoption of the system of education countrywide was implemented as a separate step from gender equality as a policy achievement, but more towards modernization of the education system in Kazakhstan. Second, accessibility of education for women is prescribed as one of the steps of sustainable development with high priority in developing countries. Third, Kazakhstan is a former member of the Soviet Union. Therefore, access to education has been equal for both genders in Kazakhstan. Accordingly, the development of women empowerment in education in Kazakhstan stands out as a separate stream from Kazakhstan's Gender Equality Policy.

\section{Conclusion}

Gender Policy is one of the main directions of the country development as it affects all fields of activities. The main limitation of this study was lack of gender statistics. Most of the available data is presented as general information. Thus, making it impossible to provide deep gender analysis.

The results of current research could be used to achieve GE goals in Kazakhstan in increasing of women participation in National Parliaments. According to the results obtained and the analysis provided we can conclude the following.
First, current study supported the theory of the context. It is important to follow cultural standards, existing norms in relation to the dimensions, which are being developed under the framework of GE policy. Governments should take into account which parts of GE policy have been already achieved or existed in the country. Next, they need to analyze their effect in order to improve GE policy. For instance, education in Kazakhstan is compulsory. Access to education for women was not as important as in the countries with limited access to education.

Second, when developing GE policy it is important to project future outcomes. As example, the growth of women labor force does not create higher representation of women in politics. Therefore, the fields of labor for women participation should be studied deeper with further projecting for future generation participation. The employment policy must predict carrier opportunities for women with possibilities of promotion to top positions.

Third, GE could be achieved not only through GE policy. As in the case of Bologna declaration adoption in Kazakhstan other issues as wage gap, low political representativeness etc, could be solved through other state pragmas or solutions. 


\section{Reference}

1. Allwood, G. (2020) Gender Equality in European Union Development Policy in Times of Crisis // Political Studies Review. - 2020. - № 18(3). - P. 329345.

2. Dugarova, E. (2019) Gender, work, and childcare in Kazakhstan, Mongolia, and Russia // Social Policy and Administration. - 2019. - № 53(3). - P. 385400 .

3. Epple, R., Schief, S. (2016) Fighting (for) gender equality: the roles of social movements and power resources // Journal For And About Social Movement. -2016 . -№ 8(2). - P. 394-432.

4. Park, S., Liang, J. (2019) A Comparative Study of Gender Representation and Social Outcomes: The Effect of Political and Bureaucratic Representation // Public Administration Review. - 2019. - № 81(2) . - P. $1-12$.

5. Nandan, A., \& Mallick, H. (2020) Does Gender Equality Matter for Regional Growth and Income Inequality? An Empirical Analysis for the Indian States //Journal of International Development. - 2020. - № 32(4). - P. 439-469.

6. Connell, R. (2006) Glass Ceilings or Gendered Institutions? Mapping the Gender Regimes of Public Sector Worksite // Public Administration Review. 2006. - № 66(6). - P. 837-849

7. Irefin. P., Ifah S.S., Bwala M.H. (2012) Organizational Theories and Analysis: A Feminist Perspective // International Journal of Advancements in Research \& Technology. - 2012. - № 1(1). - P. 1-27

8. Ghosh, T., \& Ramanayake, S. S. (2021) The macroeconomics of gender equality // International Journal of Finance and Economics. - 2021. - № 26(2). - P. 1955-1977.
9. Baker, D. B., \& Hassan, S. (2021) Gender and Prosecutorial Discretion: An Empirical Assessment // Journal of Public Administration Research and Theory. - 2021. - № 31(1). - P. 73-90.

10. Nasser, S. (2018) Boxed women in public administration-between glass ceilings and glass walls: A study of women's participation in public administration in the Arab States // Journal of International Women's Studies. - 2018. - № 19(3). - P 152-171.

11. Rizzo, H., Abdel-Latif, A. H., \& Meyer, K. (2007). The relationship between gender equality and democracy: A comparison of Arab versus non-Arab muslim societies. Sociology. - 2007. - 41(6). - P. 11511170 .

12. Moaddel, M. (2006) The Saudi Public Speaks: Religion, Gender, and Politics // International Journal of Middle East Studies. - 2006. - № 38. - P 79-108.

13. Tessler, M., E. Altinoglu (2004) Political Culture in Turkey: Connections Among Attitudes Toward Democracy, the Military and Islam // Democratization. 2004. - № 11(1). - P 21-50

14. Harrits, G. S. (2019). Stereotypes in Context: How and When Do Street-Level Bureaucrats Use Class Stereotypes? Public Administration Review. - 2019. № 79(1). - P. 93-103.

15.Kabeer, N., \& Natali, L. (2013) Gender Equality and Economic Growth : Is there a Win-Win ? // IDS Workin Papers. - 2013. - № 417. - P. 1-58

16. Hill, M. A., King, E.(1995) Women's Education and Economic Well-being // Feminist Economics. 1995. - № 1(2). - P 21-46

17.D'Agostino, M. J. (2017) Changing the Narrative: The Difference Women Make in Public Administration // Administration and Society. - 2017. № 49(1). - P. 9-19. 


\section{Information about the authors}

Kireyeva A.A. - corresponding author, PhD Institute of CS MES RK, 050010, Almaty, Kurmangazy str. 29, senior researcher, 8701690 0466, kireyeva.anel@ieconom.kz, ORCID 0000-0003-3412-3706

Kenzhegulova G.K. - NARXOZ University, 050035, Almaty, st. Zhandosova 55, PhD student, 87014522521 , gaukhar.kenzhegulova@gmail.com ORCID 0000-0002-1232-4788

Rajkhan Osama, PhD Professor of Bioethics -and Holistic Health, American University of Sovereign Nations, Saudi Arabia, osamarajkhan@gmail.com

\section{Авторлар туралы мәліметтер}

Киреева А.А. - хат-хабаршы авторы, РhD, ҚР БҒМ ҒК Экономика институты, 050010, Алматы қ., Құрманғазы к-сі, 29, ғылыми қызметкер, 8701690 0466, kireyeva.anel@ieconom.kz, ORCID 0000-0003-34123706

Кенжегулова Г.К. - НАРХОЗ университеті, 050035, Алматы қ. Жандосова 55, Докторант, 87014522521 gaukhar.kenzhegulova@gmail.com, ORCID 0000-0002-1232-4788

Раджхан О. - PhD докторы, Биоэтика және Біртұтас Денсаулық Сақтау Профессоры Американдық Егеменді Ұлттар Университеті Егеменді Ұлттар Ұйымының, Сауд Арабиясы, osamarajkhan@gmail.com

Дата поступления: 30.04.2021. Прошла рецензирование: 10.05.2021. Принято решение о публикации: 04.06.2021.

Received: 30.04.2021. Reviewed: 10.05.2021. Accepted: 04.06.2021.

Қарастыруға қабылданды: 30.04.2021.

Рецензиялауды өтті: 10.05.2021. Жариялауга қабылданды: 04.06.2021. 